\title{
MUCOCUTANEOUS MANIFESTATIONS OF HIV/AIDS AND ITS CORRELATION WITH CD4 COUNTS
}

\author{
Shivakumar Patil1, Snehal Lunge2, Prarthana Desai³, Manjunathswamy Basavapurada Swamy4 \\ ${ }^{1}$ Assistant Professor, Department of Dermatology, Jawaharlal Nehru Medical College, KLE University, Belgaum. \\ ${ }^{2}$ Assistant Professor, Department of Dermatology, Jawaharlal Nehru Medical College, KLE University, Belgaum. \\ 3Senior Resident, Department of Dermatology, Jawaharlal Nehru Medical College, KLE University, Belgaum. \\ ${ }^{4}$ Professor and HOD, Department of Dermatology, Jawaharlal Nehru Medical College, KLE University, Belgaum.
}

\section{ABSTRACT}

\section{BACKGROUND}

The study of dermatological manifestations in Human Immunodeficiency Virus (HIV) infected individuals/Acquired ImmunoDeficiency Syndrome patients is important in view of increasing morbidity and mortality associated with HIV/AIDS in the Indian scenario. This study was undertaken to observe the prevalence of various manifestations of HIV on the mucous membrane, skin and its appendages among HIV/AIDS patients attending the Skin OPD in KLE's Dr. Prabhakar Kore Hospital and MRC, Belgaum and to correlate these dermatological manifestations with their CD4 counts.

\section{MATERIALS AND METHODS}

HIV/AIDS patients attending skin OPD at KLE's Dr. Prabhakar Kore Hospital and MRC, Belgaum, with symptoms and signs of dermatological disease during the period from January 2015 to December 2015 were included. A short questionnaire recording their particulars and a detailed dermatological evaluation of the patient was done. Relevant investigations along with CD4 counts were done in all the cases.

\section{RESULTS}

Present study comprised of 126 HIV patients. Maximum number (42.85\%) of patients belonged to the 26-35 years' age group. Male-to-female ratio for the HIV reactive was 2.6:1. Sexual route (77.77\%) was the commonest probable route of transmission in the patients. Total of 69 patients (54.76\%) out of 126 presented with cutaneous manifestations. Xerosis (46.03\%) was the commonest manifestation. Commonest infectious manifestation was oral candidiasis (24 patients, 19.04\%). Nail disorders were seen in 27 patients (21.42\%). Commonest nail manifestation seen was Onychomycosis $(9.52 \%)$. Hair disorders were seen in the 55 (43.65\%) patients. Dry lustreless hair (41.26\%) was the commonest finding. In present study, 34 (26.98\%) patients were having STIs. Maximum numbers of cases of Herpes genitalis (5.55\%) were seen. In present study 68 patients (53.90\%) were in range of CD4+ count of 200-500 followed by 31 patients (24.60\%) having CD4+ count less than 200, while 27 patients (21.42\%) were found having CD4+ count more than 500 .

\section{CONCLUSION}

HIV/AIDS cases are now increasingly being found in dermatological practice. Atypical forms of diseases and manifestations like Herpes zoster, oral candidiasis, Molluscum contagiosum, Kaposi's sarcoma, Oral Hairy Leucoplakia should prompt for HIV/AIDS test of the patient, as they indicate low immunity of the patient. CD4+ count is an effective indicator to assess the immune status of the patient.

\section{KEYWORDS}

Acquired Immuno-Deficiency Syndrome; Human Immuno-Deficiency Virus; CD4+ Count.

HOW TO CITE THIS ARTICLE: Patil S, Lunge S, Desai P, et al. Mucocutaneous manifestations of HIV/AIDS and its correlation with CD4 counts. J. Evolution Med. Dent. Sci. 2016;5(73):5416-5422, DOI: 10.14260/jemds/2016/1228

\section{INTRODUCTION}

In many patients, mucocutaneous diseases are amongst one of the first recognised clinical manifestations of HIV/AIDS. Over the past decade, it has become increasingly clear that the cutaneous disorders are associated not only with terminal stages of immunodeficiency, but also occur throughout the course of HIV infection. ${ }^{1}$ Dermatological disease appears to

Financial or Other, Competing Interest: None.

Submission 31-06-2016, Peer Review 27-08-2016,

Acceptance 02-09-2016, Published 12-09-2016.

Corresponding Author:

Dr. Shivakumar Patil,

Department of Dermatology,

Jawaharlal Nehru Medical College,

KLE University,

Belgaum.

E-mail: shivakumarkpatil@gmail.com

DOI: $10.14260 /$ jemds/2016/1228 occur more frequently as the degree of immunodeficiency worsens, disrupting the normal physical barriers of the skin. ${ }^{2}$ In developed countries CD4+ lymphocyte count, detection of viral specific RNA and viral culture are used for the assessment of the HIV disease. But in developing countries lack of facilities and great cost involved in getting either CD4+ count or the viral load done, even if they are available necessitates a greater dependence on clinical markers. ${ }^{3}$ This study was done to observe the cutaneous manifestations in HIV and their correlation to CD4 counts.

\section{MATERIALS AND METHODS}

Present study comprised of 126 HIV patients, who attended the Dermatology and STD Department of KLE's Dr. Prabhakar Kore Hospital, Belgaum, between January 2015 and December 2015. Patients who were on anti-retroviral drugs at the time of presentation were not included. A detailed history of all patients was recorded as per the proforma. 
Clinical examination was carried out in detail, in natural light and was recorded. It included the examination of any lesion on the skin and mucous membrane from head to toe at the time of presentation. Examination of the genital areas and skin appendages was also carried out and recorded.

Investigations like routine blood and urine investigations were done in all cases and recorded. HIV infection was confirmed as per NACO guidelines after written consent of the patient. Patients were subjected for CD4+ lymphocyte cell count (cells $/ \mathrm{mm}^{3}$ ) irrespective of their clinical picture or stage of the disease. AIDS was diagnosed according to the AIDS defining condition and CD4+ lymphocyte count. Test for Australian antigen, Mantoux test, VDRL, histopathological examination and blood, urine, stool, pus cultures were done as and when required.

\section{RESULTS}

A total of 126 HIV-positive patients were enrolled in the study. Maximum number (42.85\%) of patients belonged to the 26-35 years' age group. Male-to-female ratio was 2.6:1. In present study, sexual route $(77.77 \%)$ was the commonest probable route of transmission. Total of 69 patients (54.76\%) out of 126 presented with cutaneous manifestations.

The mucocutaneous manifestations are classified into infectious (Table 1), non-infectious manifestations (Table 2), nail (Table 3) and hair manifestations (Table 4) and sexually transmitted infections (Table 5).

Commonest infectious manifestation was oral candidiasis (24 patients, 19.04\%). The commonest morphological pattern noticed was pseudomembranous type in 13 patients $(54.16 \%, \mathrm{n}=24)$ followed by atrophic type in 8 (33.33\%), angular cheilitis in $2(08.33 \%)$ and hyperplastic in one patient $(04.16 \%)$. Xerosis $(46.03 \%)$ was the commonest noninfectious manifestation. Nail disorders were seen in 27 patients $(21.42 \%)$. Commonest nail manifestation seen was Onychomycosis $(9.52 \%)$. Hair disorders were seen in the 55 $(43.65 \%)$ patients. Dry lustreless hair $(41.26 \%)$ was the commonest finding. In present study, 34 (26.98\%) patients were having STIs. Maximum number of cases of Herpes genitalis (5.55\%) were seen.

In present study 68 patients (53.90\%) were in range of CD4+ count of 200-500 followed by 31 patients $(24.60 \%)$ having CD4+ count less than 200, while 27 patients $(21.42 \%)$ were found having CD4+ count more than 500 (Table 6).

More than $90 \%$ patients had multiple manifestations. Herpes zoster, oral candidiasis, xerosis, intractable itching, dry lustreless hair were seen as the most commonly occurring manifestations (Table 7).

\begin{tabular}{|c|c|c|c|}
\hline Sr. No. & $\begin{array}{c}\text { Cutaneous } \\
\text { Manifestations }\end{array}$ & $\begin{array}{c}\text { No. of } \\
\text { Pts. }\end{array}$ & $\%$ \\
\hline 1. & Oral candidiasis & 24 & 19.04 \\
\hline 2. & Herpes Zoster & 21 & 16.66 \\
\hline 3. & $\begin{array}{c}\text { Superficial } \\
\text { Dermatophytosis }\end{array}$ & 15 & 11.90 \\
\hline 4. & Onychomycosis & 12 & 09.52 \\
\hline 5. & Pyodermas & 11 & 08.73 \\
\hline 6. & Extragenital MC & 6 & 04.76 \\
\hline 7. & Extragenital Warts & 4 & 03.17 \\
\hline 8. & Herpes Simplex & 3 & 02.38 \\
\hline 9. & Cryptococcosis & 1 & 00.79 \\
\hline 10. & Oral Hairy Leucoplakia & 1 & 00.79 \\
\hline \multicolumn{4}{|c|}{ Table 1: Infectious Manifestations } \\
\hline \multicolumn{4}{|c|}{} \\
\hline \multicolumn{4}{|c|}{}
\end{tabular}

\begin{tabular}{|c|c|c|c|}
\hline $\begin{array}{c}\text { Sr. } \\
\text { No. }\end{array}$ & Cutaneous Manifestations & $\begin{array}{c}\text { No. of } \\
\text { Pts. }\end{array}$ & \% \\
\hline 1. & Xerosis & 58 & 46.03 \\
\hline 2. & Intractable Itching & 41 & 32.53 \\
\hline 3. & Hyperpigmentation & 9 & 07.14 \\
\hline 4. & Lichenoid Eruption & 2 & 1.58 \\
\hline 5. & Insect Bite Reactions & 3 & 02.38 \\
\hline 6. & Recurrent Aphthous Ulcers & 3 & 02.38 \\
\hline 7. & Drug Reaction & 3 & 02.38 \\
\hline 8. & Steven-Johnson Syndrome & 3 & 02.38 \\
\hline 9. & Pruritic Papules of HIV & 1 & 00.79 \\
\hline 10. & Kaposi's Sarcoma & 1 & 00.79 \\
\hline 11. & \multicolumn{4}{|c|}{ Ichthyosis } & 1 & 00.79 \\
\hline \multicolumn{4}{|c|}{ Table 2: Non-Infectious Manifestations } \\
\hline
\end{tabular}

\begin{tabular}{|c|c|c|c|}
\hline $\begin{array}{c}\text { Sr. } \\
\text { No. }\end{array}$ & Nail Changes & No. of Pts. & $\mathbf{\%}$ \\
\hline 1. & Onychomycosis & 12 & 09.52 \\
\hline 2. & Nail discolouration & 10 & 07.92 \\
\hline 3. & Nail Dystrophy & 4 & 03.17 \\
\hline 4. & Paronychia & 4 & 03.17 \\
\hline \multicolumn{4}{|c|}{ Table 3: Nail Manifestations } \\
\hline
\end{tabular}

\begin{tabular}{|c|c|c|c|}
\hline $\begin{array}{c}\text { Sr. } \\
\text { No. }\end{array}$ & Hair Changes & No. of Pts. & $\mathbf{\%}$ \\
\hline 1. & Dry Lustreless Hair & 52 & 41.26 \\
\hline 2. & Diffuse Alopecia & 09 & 7.14 \\
\hline 3. & Premature Graying & 06 & 7.14 \\
\hline 4. & Straightening & 03 & 4.76 \\
\hline 5. & Trichomegaly & 03 & 02.38 \\
\hline \multicolumn{3}{|c|}{ Table 4: Hair Manifestations } \\
\hline
\end{tabular}

\begin{tabular}{|c|c|c|c|c|}
\hline $\begin{array}{l}\text { Sr. } \\
\text { No. }\end{array}$ & $\begin{array}{c}\text { Sexually Transmitted } \\
\text { Infections (STI) }\end{array}$ & $\begin{array}{c}\text { No. } \\
\text { of } \\
\text { Pts. }\end{array}$ & $\begin{array}{c}\% \\
(n=126)\end{array}$ & $\begin{array}{c}\% \\
(n=34)\end{array}$ \\
\hline 1. & Herpes Genitalis & 07 & 05.55 & 20.58 \\
\hline 2. & Genital MC & 05 & 03.96 & 14.70 \\
\hline 3. & Genital Warts & 04 & 03.17 & 11.76 \\
\hline 4. & $\begin{array}{c}\text { Candidal } \\
\text { Balanoposthitis }\end{array}$ & 03 & 02.38 & 08.82 \\
\hline 5. & Scabies & 02 & 01.58 & 05.88 \\
\hline 6. & Syphilis & 02 & 01.58 & 05.88 \\
\hline 7. & Chancroid & 02 & 01.58 & 05.88 \\
\hline 8. & Gonorrhoea & 02 & 01.58 & 05.88 \\
\hline 9. & LGV & 01 & 00.79 & 02.94 \\
\hline 10. & Vaginal Candidiasis & 01 & 000.79 & 02.94 \\
\hline 11. & Mixed & 5 & 03.96 & 14.70 \\
\hline
\end{tabular}

\begin{tabular}{|c|c|c|c|c|}
\hline \multicolumn{5}{|c|}{ CD4+ COUNT } \\
\hline Range & $>\mathbf{5 0 0}$ & $\mathbf{2 0 0 - 5 0 0}$ & $<\mathbf{2 0 0}$ & Total \\
\hline No. & 27 & 68 & 31 & 126 \\
\hline \% & 21.42 & 53.90 & 24.60 & $100 \%$ \\
\hline \multicolumn{5}{|c|}{ Table 6: Details of CD4 Count } \\
\hline
\end{tabular}




\begin{tabular}{|c|c|c|c|c|c|c|}
\hline \multirow{2}{*}{$\begin{array}{c}\text { CUTANEOUS } \\
\text { MANIFESTATIONS }\end{array}$} & \multicolumn{6}{|c|}{ CD 4+ COUNTS OF PATIENT (cells/mm³). } \\
\hline & $>500$ & \multicolumn{2}{|c|}{\begin{tabular}{l|l}
$200-500$ & \\
\end{tabular}} & \begin{tabular}{l|l}
$<200$ & \\
\end{tabular} & n & \multirow{2}{*}{$\begin{array}{c}\begin{array}{l}\text { Mean } \\
\text { CD 4+ }\end{array} \\
258.33\end{array}$} \\
\hline \multirow{6}{*}{$\begin{array}{l}\mathbf{I} \\
\mathbf{N} \\
\mathbf{F} \\
\mathbf{E} \\
\mathbf{C} \\
\mathbf{T} \\
\mathbf{I} \\
\mathbf{0} \\
\mathbf{U} \\
\mathbf{S}\end{array}$} & $\begin{array}{c}\text { Oral } \\
\text { Candidiasis }\end{array}$ & $\begin{array}{c}2 \\
(8.3 \%)\end{array}$ & $\begin{array}{c}6 \\
(25 \%)\end{array}$ & $\begin{array}{c}16 \\
(66.7 \%)\end{array}$ & 24 & \\
\hline & $\begin{array}{l}\text { Herpes } \\
\text { Zoster } \\
\end{array}$ & $\begin{array}{c}1 \\
(4.76 \%) \\
\end{array}$ & $\begin{array}{c}2 \\
(9.56 \%) \\
\end{array}$ & $\begin{array}{c}18 \\
(85.7 \%) \\
\end{array}$ & 21 & 192 \\
\hline & Superficial Dermatophytosis & $\begin{array}{c}1 \\
(6.66 \%) \\
\end{array}$ & $\begin{array}{c}5 \\
(33.33 \%) \\
\end{array}$ & $\begin{array}{c}9 \\
(60.00 \%) \\
\end{array}$ & 15 & 315.9 \\
\hline & Herpes Simplex & $\begin{array}{c}0 \\
(0 \%)\end{array}$ & $\begin{array}{c}0 \\
(0 \%)\end{array}$ & $\begin{array}{c}3 \\
(100.00 \%)\end{array}$ & 3 & 133.33 \\
\hline & $\begin{array}{c}\text { Extragenital } \\
\text { MC }\end{array}$ & $\begin{array}{c}0 \\
(0 \%)\end{array}$ & $\begin{array}{c}1 \\
(16.66 \%)\end{array}$ & $\begin{array}{c}5 \\
(83.33 \%)\end{array}$ & 6 & 101 \\
\hline & Pyoderma & $\begin{array}{c}3 \\
(27.27 \%) \\
\end{array}$ & $\begin{array}{c}6 \\
(54.54 \%) \\
\end{array}$ & $\begin{array}{c}2 \\
(18.18 \%) \\
\end{array}$ & 11 & 384.63 \\
\hline $\begin{array}{l}\mathbf{N} \\
\mathbf{O}\end{array}$ & Xerosis & $\begin{array}{c}13 \\
(22.41 \%)\end{array}$ & $\begin{array}{c}21 \\
(36.20 \%)\end{array}$ & $\begin{array}{c}24 \\
(41.37 \%)\end{array}$ & 58 & 337.84 \\
\hline $\mathbf{N}$ & Hyper pigmentation & $\begin{array}{c}2 \\
(22.22 \%)\end{array}$ & $\begin{array}{c}3 \\
(33.33 \%)\end{array}$ & $\begin{array}{c}04 \\
(44.44 \%)\end{array}$ & 09 & 338.88 \\
\hline $\mathbf{I}$ & Drug Reactions & $\begin{array}{c}0 \\
(0 \%) \\
\end{array}$ & $\begin{array}{c}1 \\
(33.33 \%) \\
\end{array}$ & $\begin{array}{c}2 \\
(66.66 \%) \\
\end{array}$ & 03 & 95.3 \\
\hline $\begin{array}{l}\mathbf{F} \\
\mathbf{E} \\
\mathbf{C T}\end{array}$ & Recurrent Aphthous Ulcers & $\begin{array}{c}0 \\
(0 \%)\end{array}$ & $\begin{array}{c}1 \\
(33.33 \%)\end{array}$ & $\begin{array}{c}2 \\
(66.66 \%)\end{array}$ & 03 & 250 \\
\hline $\begin{array}{l}\text { IO } \\
\text { US }\end{array}$ & $\begin{array}{l}\text { Seborrheic } \\
\text { Dermatitis }\end{array}$ & $\begin{array}{c}1 \\
(33.33 \%) \\
\end{array}$ & $\begin{array}{c}1 \\
(33.33 \%) \\
\end{array}$ & $\begin{array}{c}1 \\
(33.33 \%) \\
\end{array}$ & 03 & 300.33 \\
\hline & $\begin{array}{l}\text { Herpes } \\
\text { Genitalis }\end{array}$ & $\begin{array}{c}0 \\
(0 \%)\end{array}$ & $\begin{array}{c}1 \\
(14.29 \%)\end{array}$ & $\begin{array}{c}6 \\
(85.71 \%)\end{array}$ & 07 & 108.14 \\
\hline$S$ & Genital MC & $\begin{array}{c}0 \\
(0 \%) \\
\end{array}$ & $\begin{array}{c}0 \\
(0 \%) \\
\end{array}$ & $\begin{array}{c}05 \\
(100.00 \%) \\
\end{array}$ & 05 & 78.80 \\
\hline $\mathbf{T}$ & Genital Warts & $\begin{array}{c}0 \\
(0 \%)\end{array}$ & $\begin{array}{c}1 \\
(25.00 \%)\end{array}$ & $\begin{array}{c}3 \\
(75.00 \%)\end{array}$ & 04 & 133 \\
\hline & Candidal Balanoposthitis & $\begin{array}{c}1 \\
(33.00 \%)\end{array}$ & $\begin{array}{c}1 \\
(33.00 \%)\end{array}$ & $\begin{array}{c}1 \\
(33.00 \%)\end{array}$ & 03 & 276 \\
\hline $\begin{array}{l}\text { H } \\
\text { A }\end{array}$ & Dry Lusterless Hair & $\begin{array}{c}12 \\
(23.07 \%) \\
\end{array}$ & $\begin{array}{c}19 \\
(36.53 \%) \\
\end{array}$ & $\begin{array}{c}21 \\
(40.38 \%) \\
\end{array}$ & 52 & 349.90 \\
\hline $\begin{array}{l}\mathbf{I} \\
\mathbf{R}\end{array}$ & Diffuse Alopecia & $\begin{array}{c}1 \\
(11.11)\end{array}$ & $\begin{array}{c}3 \\
(33.33 \%)\end{array}$ & $\begin{array}{c}5 \\
(55.55 \%)\end{array}$ & 09 & 241.60 \\
\hline $\begin{array}{l}\mathbf{N} \\
\mathbf{A}\end{array}$ & Onychomycosis & $\begin{array}{c}1 \\
(8.33 \%)\end{array}$ & $\begin{array}{c}3 \\
(25 \%) \\
\end{array}$ & $\begin{array}{c}8 \\
(66.66 \%)\end{array}$ & 12 & 240.91 \\
\hline $\begin{array}{l}\mathbf{I} \\
\mathbf{L}\end{array}$ & Nail Discolouration & $\begin{array}{c}3 \\
(30 \%) \\
\end{array}$ & $\begin{array}{c}4 \\
(40 \%) \\
\end{array}$ & $\begin{array}{c}3 \\
(30 \%) \\
\end{array}$ & 10 & 323 \\
\hline
\end{tabular}

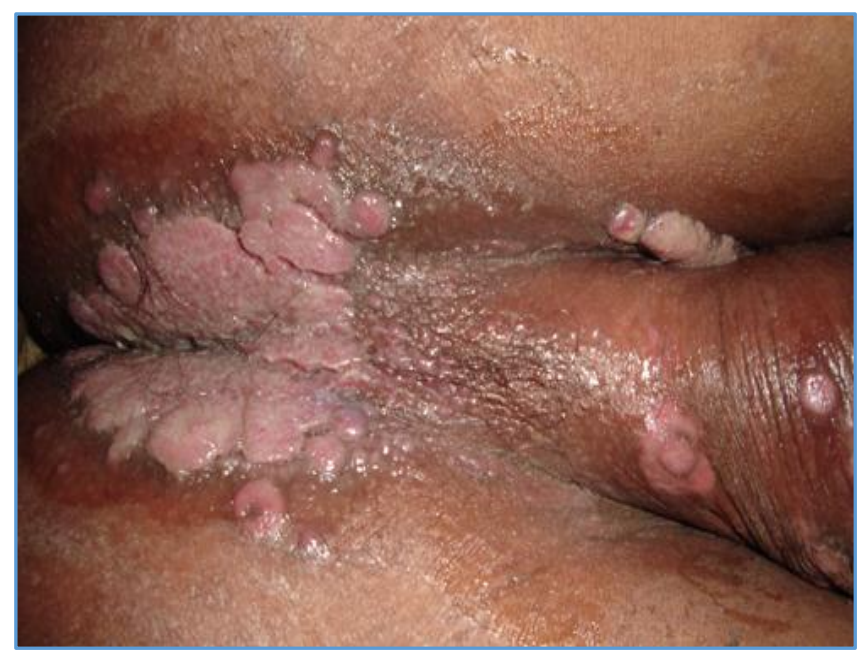

Condyloma Lata

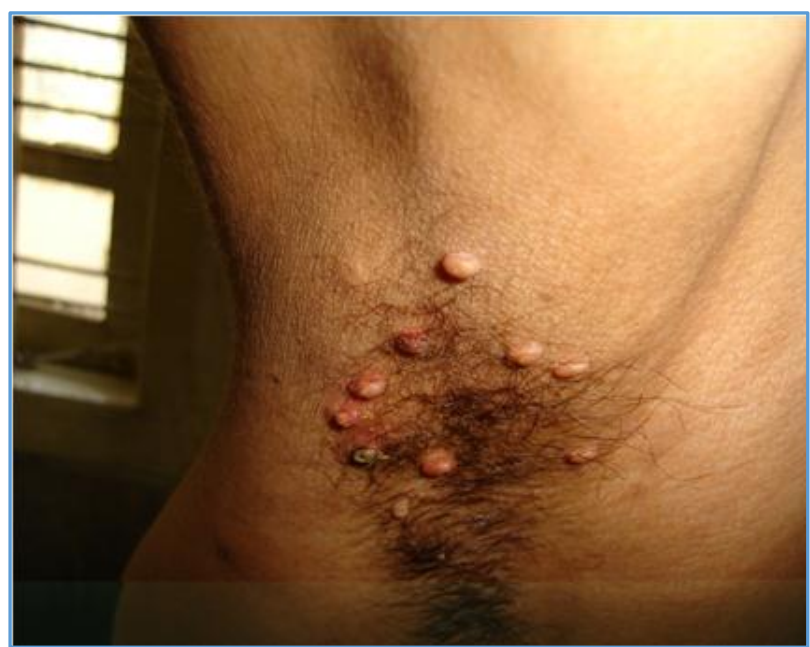

Cutaneous Cryptococcosis 


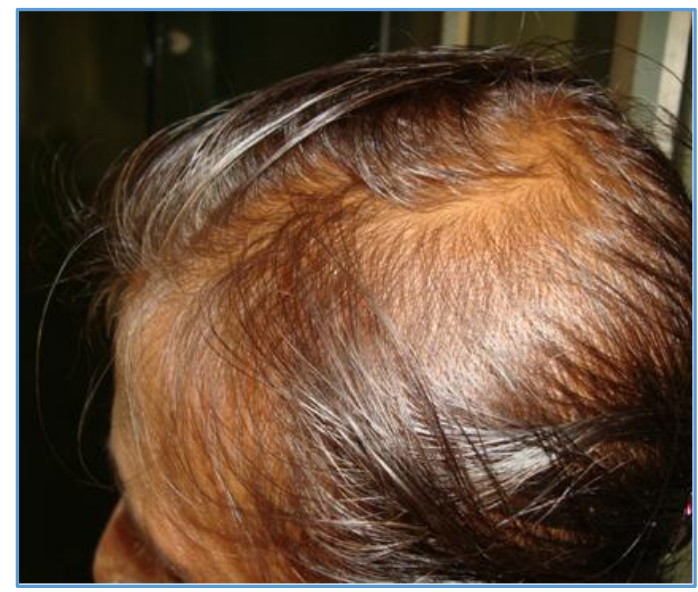

Diffuse Thinning of Hair



Genital Molluscum Contagiosum

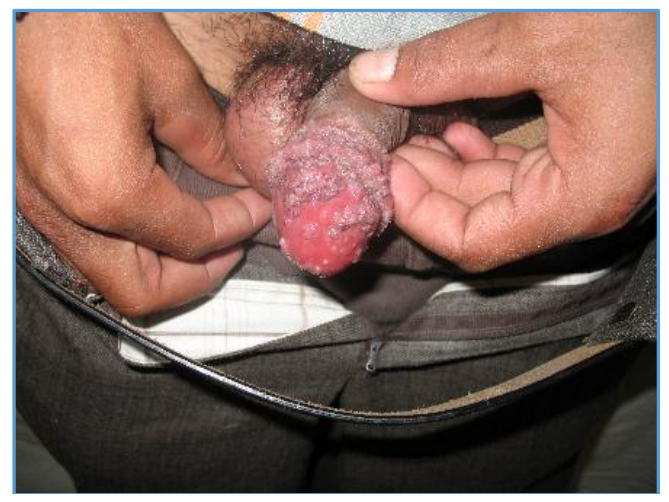

Genital Warts

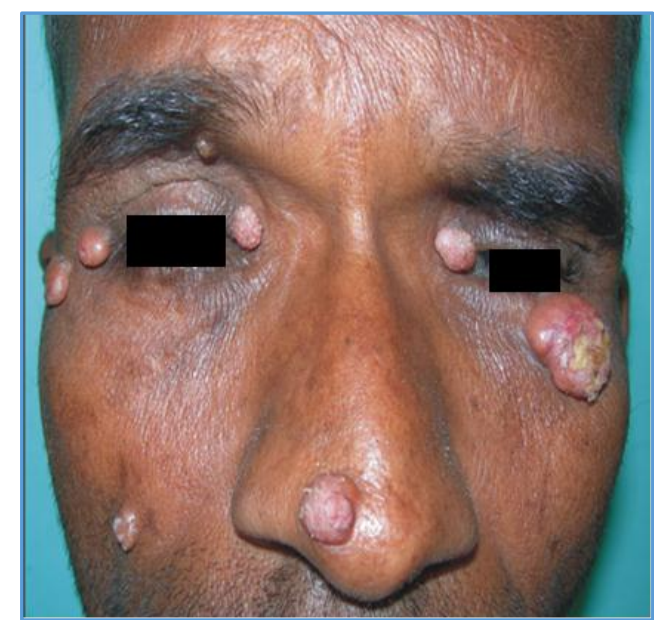

Giant Molluscum Contagiosum

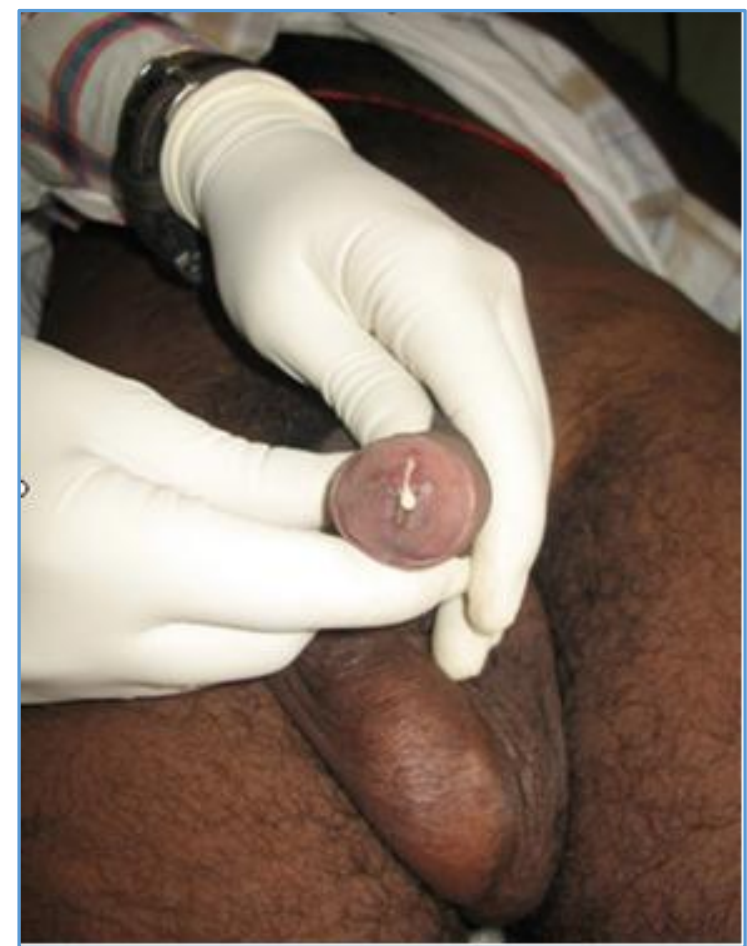

Gonococcal Urethritis



Herpes Genitalis

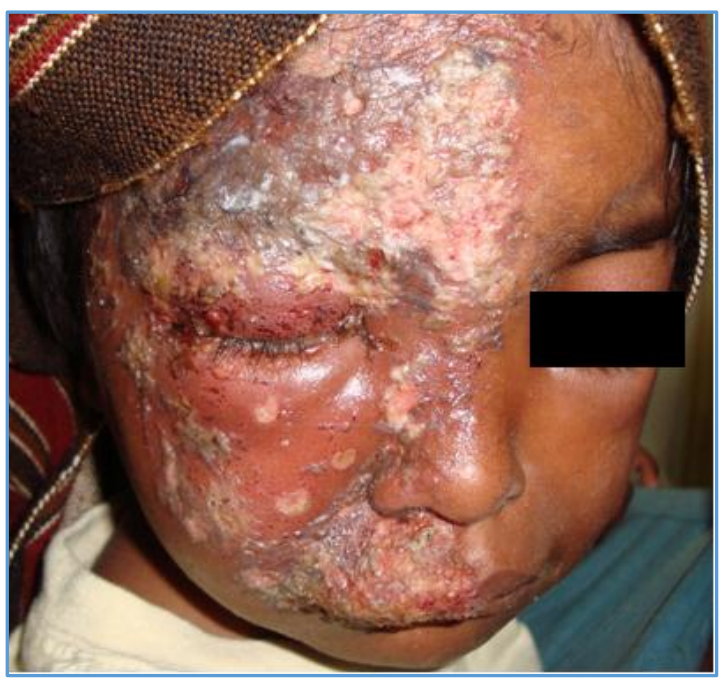

Herpes Zoster in a Child 


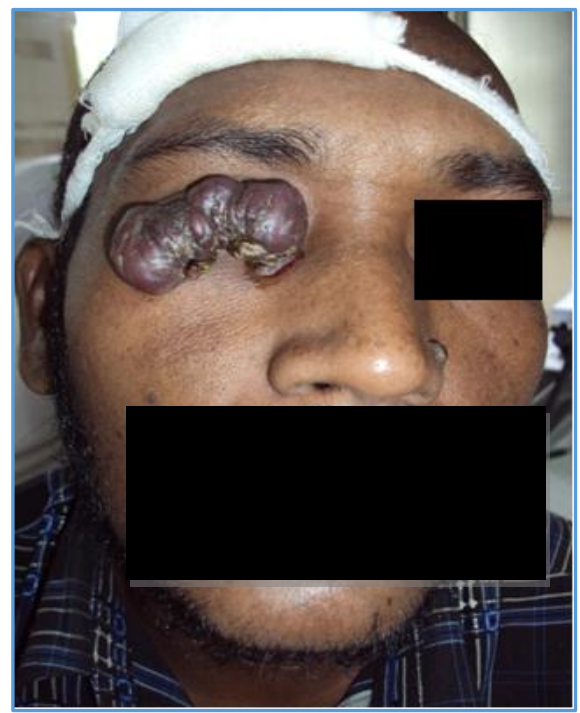

Kaposi's Sarcoma involving Orbit

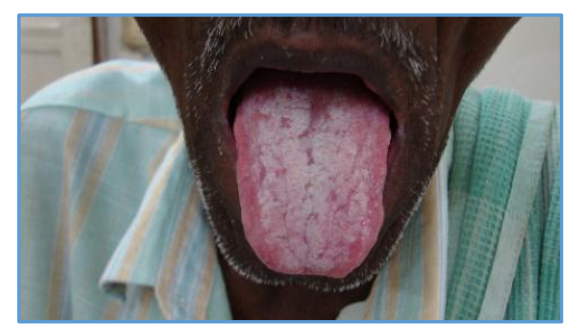

Oral Candidiasis



Oral Hairy Leukoplakia

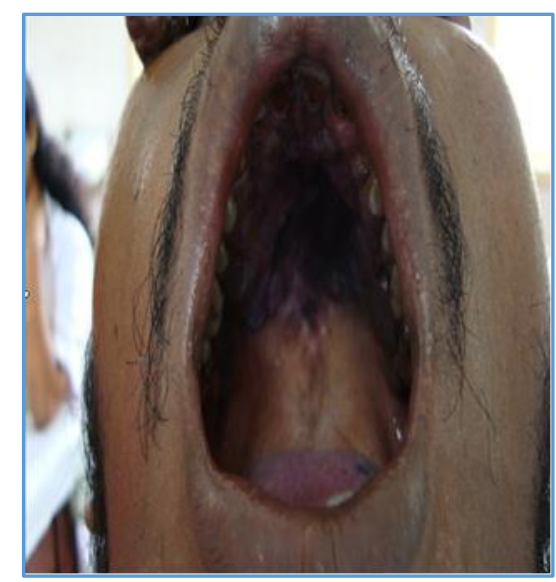

Oral Lesions in Kaposi Sarcoma

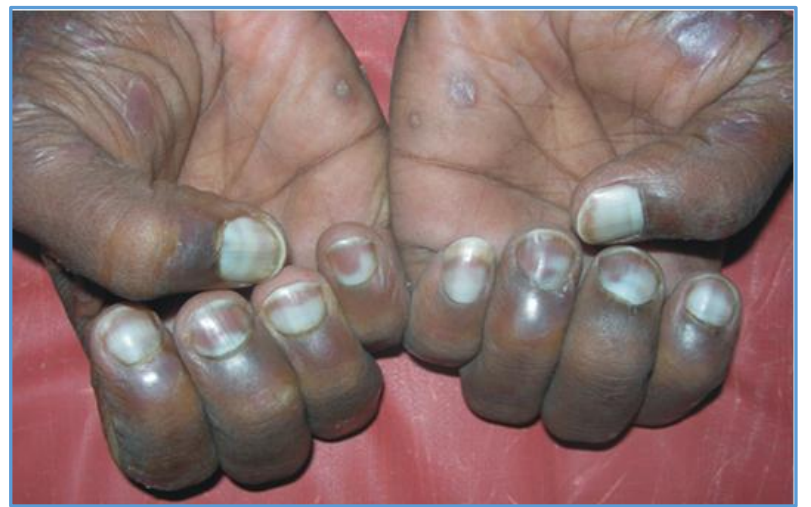

Proximal Subungual Onychomycosis

\section{DISCUSSION}

HIV infection/AIDS results in various mucocutaneous manifestations, which may be due to HIV infection itself due to decreasing immunity or due to various opportunistic infections.

In current study maximum number of patients belonged to the young age group 26-45 years (76.18\%), similar was found by Nair SP et $\mathrm{al}^{4}$ where $77.67 \%$ patients belonged to 21 to 40 years' age group. Similar was also found by Harish MR et $\mathrm{al},{ }^{5}$ Criton $\mathrm{S}$ et al, ${ }^{6}$ Ganesh $\mathrm{P}$ et $\mathrm{al}^{7}{ }^{7}$ Murugesh et al ${ }^{8}$ and Swamiappan $\mathrm{M}$ et $\mathrm{al}^{9}{ }^{9}$ where maximum numbers of patients were between similar age group. This age group is most susceptible may be because of it being sexually most active age group and also half of India's population lies within this group. Male-to-female ratio in HIV reactive patients in the present study was $2.6: 1,(\mathrm{M}=91, \mathrm{~F}=35)$. Comparable with the study of Nair SP et al, ${ }^{4}$ where $\mathrm{M} / \mathrm{F}$ ratio was $2.3: 1,(\mathrm{M}=82$, $\mathrm{F}=36$ ).

In present study, $104(82.53 \%)$ patients gave $\mathrm{H} / \mathrm{O}$ of sexual exposure. Findings are in accordance to National average of $85.34 \%$ (as per NACO 10 data) and also to study of Nair et al ${ }^{4} 78.50 \%$ and Murugesh et al 8 78\%; 8 patients gave h/o blood transfusion out of which 2 gave h/o only blood transfusion and did not have h/o sexual exposure and remaining 6 patients had h/o both blood transfusion and h/o sexual exposure; 3 patients had h/o vertical transmission. Only one patient was recorded with h/o IDU. High HIV prevalence among the IDU was observed along the national highway linking India and Myanmar ${ }^{11}$ and in North Eastern states like Manipur, neighbouring the Golden triangle. ${ }^{3}$

Total of 69 patients $(54.76 \%)$ in the present study were having one or the other mucocutaneous manifestations of HIV/AIDS cutaneous manifestations were present in $57 \%$ of patients in a study by Nair et al, ${ }^{4} 66.4 \%$ in study done by Swamiappan M et $\mathrm{al}^{9}$ and more than $50 \%$ in a study by Ganesh Pai, ${ }^{7}$ while cutaneous manifestations were found in $92 \%$ patients in a study by Murugesh et al, $8100 \%$ patients of HIV/AIDS in a study by Criton S et al. ${ }^{6}$

In present study, xerosis was the commonest finding seen in $46.03 \%$ followed by intractable itching in $41 \%$ cases. Findings are in accordance with Ganesh Pai, ${ }^{7}$ where xerosis was noted in $50 \%$ patients and pruritus was noted in $37.50 \%$ patients.

Oral candidiasis precedes most other opportunistic infection. ${ }^{3}$ The most common pattern of oral thrush in HIV/AIDS patients is the pseudomembranous type. ${ }^{3}$ Oral candidiasis was seen in $19.04 \%$ patients in the present study. 
Pseudomembranous type (54.16\%) was the most common pattern followed by atrophic type $(33.33 \%)$. The incidence of oral candidiasis in the present study is similar to the incidence reported in study by Raja B et al ${ }^{12}$ which was $9 \%$ and Swamiappan $\mathrm{M}$ et al $^{9}$ which was $19.3 \%$. While $40.6 \%$ and $45 \%$ cases respectively have been reported in studies by Ganesh Pai $^{7}$ and Kumarasamy et al.13 The large variation in the incidence may be due to various factors like malnutrition, poverty, oral hygiene, trauma due to sharp tooth, tobacco chewing which vary in different groups included in various studies.

Pigmentation, half and half nail, clubbing, onychomycosis, paronychia, yellow nail syndrome are seen in patients of HIV/AIDS.11,14 In present study, Onychomycosis was the commonest manifestation seen $(9.52 \%)$ followed by Nail discolouration (7.92\%) and Nail dystrophy (3.17\%). Mean CD4+ count of onychomycosis was 240.91 , out of 12 patients $66.66 \%$ of patients had CD $4+$ count below 200.

Lustreless hair, thin hair, various types of alopecia, discoloration of hair, graying of hair, long eye lashes are found in HIV/AIDS patients. ${ }^{11}$ In present study, dry lustreless hair was the commonest manifestation seen $(41.26 \%)$ followed by diffuse hair loss (07.14\%) and graying of hair $(04.76 \%)$. Lustreless hair could be a secondary change attributable to the nutritional status of the patients. Low hygiene status could also be one of the contributory factors for dry lustreless hairs. Trichomegaly (long eye lashes) was seen in $2.38 \%$ of patients in present study. Mean CD4+ count of dry lustreless hair was 349.90 and for diffuse hair loss was 241.60 .

In present study STI was seen in $34(26.98 \%)$ patients, out of them Herpes genitalis was seen in 7 patients $(20.58 \%$ when $\mathrm{n}=34$ ) and other 3 patients had $\mathrm{H}$. genitalis along with other STIs. In advanced HIV disease, the lesions of herpes genitalis are atypical, large, painful and deep with raised margin which was seen in two patients in present study.

Genital MC was seen in $14.70 \%$ and genital warts were seen in $11.76 \%$ patients in present study. Incidence of syphilis is decreasing after the advent of antibiotics and also because of their liberal use by the medical practitioners. Syphilis in present study was seen in 2 patients $(5.88 \%$ when $\mathrm{n}=34)$. Only $2(5.88 \%)$ male patients in present study were having gonococcal urethritis. In females, HIV patients may also present with vaginal candidiasis due to HIV related immunosuppression and frequent use of broad-spectrum antibiotics administered for prophylactic and therapeutic usage. ${ }^{3}$ It was seen in $02.94 \%$ patients in present study.

In present study in patients of $\mathrm{HZ}, 85.7 \%$ patients had CD4+ count below 200, while mean CD4+ count was for all patients of $\mathrm{HZ}$ was 192 . Ghate et $\mathrm{al}^{15}$ has reported CD4+ count 179 , Kumarasamy ${ }^{13}$ has reported 176 , Perez $M$ et al 16 has reported 286 and Jing W et al ${ }^{17}$ has reported 89.

All 3 patients of H. simplex had CD4+ count was below 200 (mean - 133); 5 out of total 6 patients of M. contagiosum were having CD4+ count below 200 (mean 101). In present study, only 1 patient of OHL was found whose CD4+ count was 40 .

Present study shows that viral infection is common with low CD4+ count. Similar was observed in studies by Jing W et $\mathrm{al}^{17}$ and Ghate et $\mathrm{al}^{15}$ where they found viral infections with low mean CD4+ counts.
In present study out of 24 patients of oral Candidiasis $66.7 \%$ patients had CD4+ counts below 200, while 25\% patients had CD4+ counts between 200 to 500; (mean - 258). Ghate et $\mathrm{al}^{15}$ has reported CD4+ count 151 , Kumarasamy ${ }^{13}$ has reported 196, Perez $M$ et al 16 has reported 134 and Jing $\mathrm{W}$ et al 17 has reported 53 . There is a wide variation in CD4+ count in patient of oral candidiasis in various studies. Reasons may be that oral candidiasis depends upon various other factors like malnutrition, poverty, oral hygiene, trauma due to sharp tooth, tobacco chewing which influence its occurrence along with low immune status.

Out of 15 patients of superficial dermatophytosis, 9 had CD4+ count below 200 (mean-316). Candidal balanoposthitis was observed in 3 patients only and all of them belongs to wide range of CD4+ counts (less than 200, 200-500, >500, mean 276). Superficial dermatophytosis infection also depends upon the various factors like environmental conditions (humidity), localised trauma (friction) and personal hygiene/care.

Out of 12 patients of onychomycosis, 8 patients were found having CD4+ count $<200$.

Only 1 patient of Cryptococcosis was found with CD4+ count of 38 .

Out of 11 patients of pyoderma $54.54 \%$ had CD $4+$ count between 200 and 500, 27.27\% had above 500 and 18.18\% had CD4+ count below 200. The mean CD4+ count was 384.63. The above findings reflect that viral and fungal skin manifestations are associated with low CD4+ counts, whereas bacterial skin infections are not much influenced by decreasing immunity.

In present study out of 7 patients of $\mathrm{H}$. genitalis, 6 patients were having CD4+ counts less than 200 (mean 108). Kumarasamy ${ }^{13}$ has reported CD4+ 196, Perez $M$ et al 16 has reported 185 and Jing $W$ et al ${ }^{15}$ has reported 130 . But in overall, all studies reflect that viral infections whether it is dermatological or genital low CD4+ count is more commonly found. All the patients of genital MC (5) were having a CD4+ count below 200 and the mean CD4+ count was 79 . Kumarasamy ${ }^{13}$ has reported $C D 4+277$, Perez $M$ et al ${ }^{16}$ has reported 98 and Jing $\mathrm{W}$ et al ${ }^{17}$ has reported 13.

Out of 4 patients of genital warts, 3 had CD4+ counts below 200 (mean -133). Perez M et al16 has reported 266 and Jing W et al17 has reported 117.

In present study it has been observed that Hair and Nail manifestations - dry and lusterless hair, diffuse alopecia, nail discolouration did not show any direct and specific relationship with CD4+ counts. May be it is more of subjective symptoms and related with nutritional status and personal hygiene and care/medications.

In present study it has also been observed that xerosis, hyperpigmentation, seborrheic dermatitis, etc. did not show any direct and specific relationship with CD4+ counts. Various studies also reported wide variations of CD4+ counts that is $4417 / 17916$ in xerosis. May be it is more of subjective symptoms and related with nutritional status and personal hygiene and care/medications.

All 4 patients who were having maximum number of cutaneous manifestations, 3 had CD4+ count below 200 .

Drug reaction was observed only in 3 patients with mean CD4+ count of 95 and it has direct relationship with CD4+ count. 


\section{CONCLUSION}

HIV/AIDS cases are now increasingly being found in dermatological practice. All dermatologists should have adequate and updated knowledge of the various mucocutaneous manifestations. This would help not only in diagnosis of HIV/AIDS, but also in further management of the patients.

Atypical forms of diseases and manifestations like $\mathrm{H}$. zoster, oral candidiasis, Molluscum contagiosum, Kaposi's sarcoma, OHL should prompt for HIV/AIDS test of the patient. CD4+ count is an effective indicator to assess of the immune status of the patient. Manifestations like H. zoster, Oral candidiasis, Molluscum contagiosum indicate low immunity of the patient and should lead for active search of other systemic co-infections in the patient.

The epidemiological profile shows that the young productive age group forms the major part of the HIV/AIDS patients. This hints towards the burden over the economy of the country in terms of loss of productive days and manpower and the money spent on the treatment of the diseases. Also it shows the need to educate and counsel risk group regarding HIV/AIDS and other STIs.

\section{REFERENCES}

1. Goldstein B, Berman B, Sukenik E, et al. Correlation of skin disorders with CD4 lymphocyte counts in patients with HIV/AIDS. J Am Acad Dermatol 1997;36(2 Pt 1):262-4.

2. Rosen T, Spedale JH. Relationships between sexually transmitted diseases and HIV infection. In: Current problems in dermatology. Harris PS, Saag MS, eds. Published at California, Mosby Publishers 1997;9(6):217-58.

3. Kumar B, Gupta S. Sexually transmitted infections: printed in India. Elsevier Publishers 2006:pg 63-66, 673693, 785-799.

4. Nair SP, Moorty KP, Suprakasan S. Clinicoepidemiological study of HIV patients in Trivandrum. Indian J Dermatol Venereol Leprol 2003;69(2):100-3.

5. Harish MR, Shanmukhappa, Kumar S, et al. A study of cutaneous manifestations in HIV infected persons. J Indian Med Assoc 2012;110(10):726-7, 731.
6. Criton S, Mohan KB, Asokan PU. Dermatological manifestations of human immunodeficiency virus infected/ acquired immunodeficiency syndrome patients in a referral hospital of central Kerala. Indian J Dermatol Venereol Leprol 1995;61(2):89-90.

7. Bhandary PG, Kamath NK, Pai GS, et al. Cutaneous manifestations of HIV infection. Indian J Dermatol Venereol Leprol 1997;63(1):35-7.

8. Murugesh SB, Nandini AS, Ravindra K, et al. A clinical study of mucocutaneous manifestations of HIV. Journal of Evolution of Medical and Dental Sciences 2014;3(44):10930-45.

9. Swamiappan M, Chandran V, Ramasamy S, et al. Pattern of mucocutaneous manifestations of HIV infected patients: a retrospective study. J Evolution Med Dent Sci 2016;5(59):4060-3.

10. http://www.nacoonline.org/facts_overview.htm.

11. Sharma VK. Sexually transmitted disease and AIDS. $1^{\text {st }}$ edn. Printed at New Delhi, Viva Publishers 2003:pg 5-7, $13,53,55,62,65,68,81,88-93$.

12. Rajagopalan B, Jacob M, George S. Skin lesions in HIV positive and HIV negative patients in south India. Int J Dermatol 1996;35(7):489-92.

13. Kumaraswamy N, Solomon S, Madhivanan $P$, et al. Dermatologic manifestations among human immunodeficiency virus patients in south India. Int J Dermatol 2000;39(3):192-5.

14. Scher RK, Daniel CR. NAILS: diagnosis, therapy and surgery. $2^{\text {nd }}$ ed. WB Sounders Company, Philadelphia 1997:101-350.

15. Ghate M, Mehendale SM, Mahajan B, et al. Relationship between clinical conditions and CD4 count in HIV infected person in Pune, Maharastra, India. Nat Med J Ind 2000;13(4):183-7.

16. Muñoz-Pérez MA, Rodriguez-Pichardo A, Camacho F, et al. Dermatological findings correlation with CD4 lymphocyte count in a prospective 3 year, study of 1161 patients with HIV diseases predominantly accquired through I/V drug abuse. Br J Dermatol 1998;139(1):33-9.

17. Jing $\mathrm{W}$, Ismail R. Mucocutaneous manifestations of HIV infection: a retrospective analysis of 145 cases in a Chinese population in Malayasia. Int J Deramtol 1999;38(6):457-63. 